\title{
Heat stress-induced changes in shoot and root characteristics of genotypes of tepary bean (Phaseolus acutifolius A. Gray), common bean (Phaseolus vulgaris L.) and their interspecific lines
}

\section{Ligia Carmenza Muñoz ${ }^{1 *}$, Mariela Rivera ${ }^{2}$, Jaime E. Muñoz ${ }^{1}$, Fatma Sarsu ${ }^{3}$ and Idupulapati M. $\mathbf{R a O}^{2 * *}$}

\author{
1Universidad Nacional de Colombia- sede Palmira, Carrera 32, Chapinero, Palmira, Colombia \\ ${ }^{2}$ Centro Internacional de Agricultura Tropical (CIAT), A.A 6713, Cali, Colombia \\ 3Plant Breeding and Genetics Section, Joint FAO/IAEA Division, NAFA, Austria
}

\author{
**Present address: Plant Polymer Research Unit, National Centre for Agricultural Utilization \\ Research, Agricultural Research Service, United States Department of Agriculture, 1815 North \\ University Street, Peoria, IL 61604, USA
}

*Corresponding author: 1cmunozf@unal.edu.co

\begin{abstract}
Heat stress is a major limitation to grain yield in common bean (Phaseolus vulgaris L.). Tepary bean (Phaseolus acutifolius A. Gray) is better adapted to heat stress than common bean. Ten tepary bean accessions, four common bean genotypes and four interspecific lines involving $P$. vulgaris and $P$. acutufolius, $P$. coccineus and $P$. dumosus were evaluated for tolerance to heat stress conditions induced under greenhouse conditions and these were compared to plants grown under ambient temperatures. The high temperature treatment was $29 \pm 5^{\circ} \mathrm{C}$ during the day and was $>24{ }^{\circ} \mathrm{C}$ (up to $27^{\circ} \mathrm{C}$ ) during the night, while the ambient temperature (AT) treatment was $25 \pm 5{ }^{\circ} \mathrm{C}$ during the day and $19 \pm 2{ }^{\circ} \mathrm{C}$ at night. The genotypic differences were evaluated for morpho-physiological characteristics of shoot and root and also yield components. The Genotype and Genotype $\times$ Temperature interactions were significant for all shoot and root morpho-physiological characteristics evaluated. Higher temperature (HT) significantly affected leaf photosynthetic efficiency, total chlorophyll content, and stomatal conductance. The effect was positive or negative, depending on the genotypes. Tepary accessions showed reduced total chlorophyll content, while common bean genotypes and the interspecific lines were less affected. Tepary accessions also showed reduced stomatal conductance, but increased leaf photosynthetic efficiency under HT. Common bean genotypes increased stomatal conductance and decreased leaf photosynthetic efficiency. High temperature decreased total root length, specific root length and pod biomass compared to ambient conditions, but there was no marked effect on pollen viability of the tested genotypes. The superior adaptation of tepary germplasm accessions to high temperature is attributed to their ability to regulate stomatal opening and photosynthetic efficiency, together with a superior ability to remobilize photosynthates from older leaves to pods during physiological maturity.
\end{abstract}

Keywords: Abiotic stress; bean crop improvement; chlorophyll content; heat tolerance; photosynthetic efficiency; stomatal conductance. Abbreviations: AT, ambient temperature; DAS, days after sowing; LA, leaf area; HT, higher temperature; PCA, Principal Component Analysis; QY, Efficiency of photosystem II; SPAD, Soil Plant Analysis Development.

\section{Introduction}

Current climate change estimates predict a rise in global temperatures between $1.4^{\circ} \mathrm{C}$ and $3{ }^{\circ} \mathrm{C}$ by 2050 and regionspecific variability in precipitation (IPCC, 2007). These dramatic climate scenarios over the short-term result in worrying predictions of crop yield reduction, especially in abiotic stresssensitive crops such as common bean (Porch et al., 2013). Common bean, Phaseolus vulgaris L., is a key grain legume crop and a vital source of nutrition worldwide. However, abiotic and biotic constraints to its production result in an average global yields of $600 \mathrm{~kg} \cdot \mathrm{ha}^{-1}$ (Porch et al., 2013). Common bean originated from the highlands of Central America and the Andes (Gepts and Debouck, 1991). The optimal average daily temperature for reproductive development ranges from $20^{\circ} \mathrm{C}$ to $25^{\circ} \mathrm{C}$. Temperatures $>30^{\circ} \mathrm{C}$ during the day or $>20^{\circ} \mathrm{C}$ during the night result in yield reduction (Rainey and Griffiths, 2005a). Heat sensitivity is a major limiting factor in the production of common bean, causing reduced yields, lower product quality and restricted geographical adaptation (Rainey and Griffiths, 2005b).
As an ecologically contrasting species, Phaseolus acutifolius A. Gray (tepary bean) is grown as a traditional crop of desert and semi-arid regions of Mexico and southwestern USA (Freeman, 1912; Nabhan and Felger, 1978). Tepary bean is cultivated successfully in places where high temperature and drought are common, making it a valuable crop for dryland environments. Compared to common bean, tepary bean possesses many traits that enable it to flourish in hot and dry regions. It is more heat tolerant at the tissue level and produces more leaves to compensate for reduced leaf size due to heat stress (Lin and Markhart, 1996). The substantially greater level of heat tolerance in tepary bean, compared with common bean, has been attributed to a lower level of sensitivity of the mitochondrial electron transport metabolism during photosynthesis (Lin and Markhart, 1990). Tepary bean also has a more extensive and thinner root system, better stomatal 
control and more active para-heliotropism than common bean (Markhart., 1985; Bielenberg et al., 2003; Butare et al., 2012). Tepary bean is part of the tertiary gene pool of common bean and is considered as a potential gene donor of heat-tolerance traits to common bean through interspecific hybridization (Muñoz et al., 2004; Blair et al., 2012). It is also considered as a valuable crop for dryland environments by itself or through inter-specific breeding (crosses between tepary bean and common bean, Mejia et al., 1994). An evaluation of tepary bean genome introgression showed that tepary DNA can be transferred to the interspecific progeny (Muñoz et al., 2004). But success is limited to a lower than expected percentage of genome contribution (Blair et al., 2012). The introgression of heat or drought tolerance from tepary into common bean might be feasible through breeding to generate elite lines that could tolerate up to $4{ }^{\circ} \mathrm{C}$ higher than the normal range of temperature tolerance (Muñoz et al., 2004, 2006).

The main objectives of this study were to: (i) determine phenotypic differences in heat stress-induced changes in shoot and root morpho-physiological characteristics of tepary bean and common bean and their interspecific lines; and (ii) identify heat tolerant genotypes that could serve as parents in breeding programmes that aim to improve heat tolerance in common bean.

\section{Results}

Effect of temperature on shoot and root morphophysiological characteristics

\section{Shoot traits}

The total shoot biomass at mid-pod filling include: stem, leaf, dead leaf and the pod biomass. There was no difference of production of shoot biomass between high temperature (HT) and ambient temperature (AT) treatments. However, the average was higher under HT (13.1g/plant) compared to the AT ( $8.6 \mathrm{~g} /$ plant) mostly because of the superior performance of both tepary accessions and interspecific lines. There were differences between the genotypes and the interaction between the Genotype $\mathrm{x}$ Temperature condition $(\mathrm{P} \leq 0.05)$ in the combined analysis. There were also differences between genotypes $(\mathrm{P} \leq 0.01)$ under $\mathrm{AT}$ but not under HT conditions.

Under HT and AT, the interspecific lines showed the highest production of shoot biomass, compared to tepary accessions and common bean lines. But the shoot biomass production was higher under HT (Table 2). Under AT, differences $(\mathrm{P} \leq 0.05)$ between the average values of shoot biomass were observed between the genotypes that showed the highest average: DAB 295 (common bean) G40022, G40159 (tepary) and ALB 91 and INB 827 (interspecific) and the genotypes: Calima (common bean) and G40001 (tepary) that produced the lowest average shoot biomass (Table 2).

\section{Pod biomass and number of pods}

There was no difference in pod biomass ( $\mathrm{g} /$ plant) between HT and AT, but the average was higher under HT ( $6.1 \mathrm{~g} / \mathrm{plant})$ compared to AT (4.4 pods/plant) condition. There were only differences between the genotypes $(\mathrm{P} \leq 0.01)$ in the combined analysis and under AT conditions $(\mathrm{P} \leq 0.01)$. The tepary accessions showed a higher pod biomass $(7.9 \mathrm{~g} /$ plant $)$ than the common bean ( $2.7 \mathrm{~g} /$ plant $)$ or the interspecific lines ( $4.9 \mathrm{~g} /$ plant $)$ under HT (Table 2). A significant difference $(\mathrm{P} \leq 0.01)$ was observed between the G40001 accession versus common bean and the interspecific lines. Differences were also observed between common bean versus interspecific lines. Under AT, the tepary accessions showed a higher pod biomass (5.7 g/plant), compared to common bean (1.5 g/plant) and the interspecific lines (4.1 g/plant) (Table 2). Differences $(\mathrm{P} \leq 0.01)$ were observed between the G40001 versus tepary accessions and the interspecific lines $(\mathrm{P} \leq 0.01)$. A highly significant difference ( $\mathrm{P}$ $\leq 0.01$ ) was also observed between tepary versus common bean and common bean versus the interspecific lines, for the pod biomass under AT.

For the number of pods, there was no difference between HT and AT treatments, but the average was higher under HT conditions (12.3 pods/plant), compared to AT treatment (8.6 pods/plant). There were differences between the genotypes and Genotype $x$ Temperature interactions $(P \leq 0.01)$ in the combined analysis. Also, there were differences $(\mathrm{P} \leq 0.01)$ between genotypes under HT and AT. Under HT, the interspecific lines showed the highest number of pods/plant (14.3) followed by tepary (12.4) and common bean genotypes (9.4) (Table 2). Under AT, tepary showed a higher number of pods/plant (10.7) compared to common bean (4.4) and the interspecific lines (7.3) (Table 2). There were average differences $(\mathrm{P} \leq 0.05)$ in pod number between the two tepary accessions (G40159 and G40022) that showed the highest number of pods / plant (17 to 18) and the total group of common beans and the interspecific lines (Table 2).

\section{Dead leaf biomass}

Under AT, there were differences in dead leaf biomass between the genotypes and the Genotype $\mathrm{x}$ Temperature interaction $(\mathrm{P} \leq$ $0.05)$ in the combined analysis. The average was higher (2.65 $\mathrm{g} /$ plant) under HT condition compared to AT (0.19 g/plant). There were differences in the production of dead leaves at the mid-pod filling growth stage, between the genotypes $(\mathrm{P} \leq 0.05)$ but only in the combined analysis. Under HT conditions the tepary accessions showed the highest production of dead leaves at mid-pod filling (4.58 g/plant), while the common bean and interspecific lines showed values lower than $1 \mathrm{~g} /$ plant (Table 2). The three tepary bean accessions: G40022, G40001 and G40200 showed a remarkable high average production of dead leaves at mid-pod filling (15.8, 14.8 and $10.9 \mathrm{~g} /$ plant, respectively) (Table 2). The other tepary, common bean genotypes and the interspecific lines showed an average production of dead leaves at mid-pod filling lower than $1 \mathrm{~g} /$ plant. Differences $(\mathrm{P} \leq 0.05)$ were observed between all groups of genotypes that were compared. Under AT all genotypes, showed a production of dead leaves at mid-pod filling, lower than $1 \mathrm{~g} /$ plant (Table 2).

\section{Root traits}

With respect to root length and biomass, there was no difference between HT and AT treatments, but the average root length was higher under the AT $(1,645 \mathrm{~cm} /$ plant), compared to HT $(1,318$ $\mathrm{cm} /$ plant), whereas root biomass was higher under HT (1.02 $\mathrm{g} /$ plant) compared to AT ( $0.78 \mathrm{~g} / \mathrm{plant})$. For both traits, there were differences between genotypes $(\mathrm{P} \leq 0.01)$ in the combined analysis and also under HT and AT ( $\mathrm{P} \leq 0.01$, data not shown). Under HT, the tepary accessions showed the lowest average root length $(937 \mathrm{~cm} /$ plant) and biomass $(0.67 \mathrm{~g} /$ plant $))$ compared to the common bean $(1,762 \mathrm{~cm} /$ plant and $1.13 \mathrm{~g} / \mathrm{plant}$, respectively) and the interspecific lines $(1,828 \mathrm{~cm} /$ plant and 1.73 $\mathrm{g} /$ plant $)$. Differences $(\mathrm{P} \leq 0.05)$ in root length were observed between the G40001 accession and common bean lines and also the interspecific lines, while the root biomass trait showed differences ( $\mathrm{P} \leq 0.01$ ) only between this accession and the interspecific lines. A significant difference $(\mathrm{P} \leq 0.05$ and $\mathrm{P} \leq$ 0.01 ) was observed between the tepary accessions, the common bean and the interspecific lines for root length and biomass, respectively. The difference between the common bean and the interspecific lines was only significant $(\mathrm{P} \leq 0.05)$ for root biomass (data not shown). Under AT, the same trend was observed as under HT condition, tepary showed the lowest average root length and biomass $(1,196 \mathrm{~cm} /$ plant and $0.53 \mathrm{~g} / \mathrm{plant}$, respectively) compared to the common bean $(1,935 \mathrm{~cm} /$ plant and $0.89 \mathrm{~g} /$ plant $)$ and interspecific lines $(2,479 \mathrm{~cm} /$ plant and 1.28 $\mathrm{g} /$ plant). There were differences between all groups of genotypes compared for root biomass, while differences $(\mathrm{P} \leq 0.05)$ in root length were observed only 
between G40001 accession versus the interspecific lines and tepary versus common bean and interspecific lines $(P \leq 0.01)$. There were differences $(\mathrm{P} \leq 0.05)$ in the average diameter of roots between HT and AT in the combined analysis. But there was no difference between genotypes in any of the analyses (data not shown).

High temperature, reduced specific root length (relation between root length and root biomass of the plant) in all Phaseolus genotypes evaluated, indicating that roots are thinner under heat stress. Under HT and AT, the common bean lines showed higher specific root lengths, while tepary accessions showed intermediate and the interspecific lines showed the lowest values (Table 2). Under HT, tepary accessions showed low values for total root length and an intermediate specific root length (Table 2 ), indicating that the roots were relatively short and with average thickness. Common bean showed higher values of total root length and higher values of specific root length, indicating that the roots were relatively long and thin, while the interspecific lines showed intermediate values for both total root length and specific root length, indicating that these roots were relatively long and moderately thick. The same trend was observed under AT conditions.

\section{Days to flowering}

The average number of days to flowering (31 days) did not differ between HT and AT treatments (Table 3). There were differences $(\mathrm{P} \leq 0.01)$ between genotypes in the combined analysis and also under HT and AT. HT induced early flowering in tepary, 26 days after sowing (DAS), compared to common bean, 40 DAS and the interspecific lines, 34 DAS (Table 3). Differences $(\mathrm{P} \leq 0.01)$ were observed between the G40001 accession and common bean and also with the interspecific lines. A highly significant difference $(\mathrm{P} \leq 0.01)$ was observed between: the tepary accessions, the common bean and the interspecific lines. The difference between the common bean and the interspecific lines was significant $(P \leq 0.01)$. Under AT, the time to flowering was reduced for the common bean lines, while in tepary and the interspecific lines, the time to flowering was little affected (Table 3). A highly significant difference ( $\mathrm{P} \leq$ 0.01 ) was observed between the tepary accessions, the common bean and the interspecific lines. In relation to the pollen viability, there was no difference between HT and AT, for the 18 genotypes tested (data not shown).

\section{Leaf area production}

There were differences in leaf area (LA) production between genotypes and the Genotype $\mathrm{x}$ Temperature interaction $(\mathrm{P} \leq$ $0.01)$ in the combined analysis. The average was higher under HT $\left(721 \mathrm{~cm}^{2}\right)$ compared to AT $\left(429 \mathrm{~cm}^{2}\right)$. There were differences between genotypes $(\mathrm{P} \leq 0.01)$ under HT and AT. Under HT, tepary showed a lower value of LA (327 $\mathrm{cm}^{2} /$ plant), compared to common bean $\left(1,198 \mathrm{~cm}^{2} /\right.$ plant $)$ and interspecific lines (1213 $\mathrm{cm}^{2} /$ plant, Table 3).

\section{Photosynthetic efficiency}

The combined analysis showed that temperature had a significant effect $(\mathrm{P} \leq 0.05)$ on leaf chlorophyll content (SPAD readings), QY (quantum yield) efficiency of photosystem II, and leaf stomatal conductance. The SPAD reading was higher in AT (39.8) compared to HT (30.8). The efficiency of photosystem II variable showed higher values (0.66) under HT compared to AT (0.58). There were significant differences $(\mathrm{P} \leq 0.01)$ in both variables among genotypes and for the Genotype $\mathrm{x}$ Temperature interaction. There was an interaction with leaf stomatal conductance $(\mathrm{P} \leq$ 0.01). The analysis under HT showed differences between genotypes for leaf chlorophyll content SPAD readings and the efficiency of photosystem II, while under the AT, only SPAD readings and leaf stomatal conductance showed differences among the genotypes. Under HT condition, tepary showed a lower average value (26.3) in SPAD readings, compared to common bean (34.1) and the interspecific lines (37.2). Differences $(\mathrm{P} \leq 0.05)$ were only observed between tepary and common bean and between tepary and the interspecific lines (Table 3).Under HT, the SPAD readings in tepary accessions decreased markedly: the values were reduced from 42.3 in AT to 26.3 under HT (Table 3). The average values of SPAD readings in the common and the interspecific lines were not affected significantly (Table 3 ). Highly significant differences $(\mathrm{P} \leq 0.01)$ between the G40001 accession versus common bean lines, between tepary accessions versus common bean and between common bean and interspecific lines $(\mathrm{P} \leq 0.05)$ were observed. Under the HT treatment, there was no difference in average QY efficiency of photosystem II, between tepary and the interspecific lines (0.68), while the common bean lines showed a lower value (0.57). Under AT, the common bean and the interspecific lines showed the same value $(0.60)$, while tepary showed a lower value $(0.57)$ (Table 3). With respect to the leaf stomatal conductance, tepary accessions showed a lower average (227) compared to common bean (312) and interspecific lines (323) under HT (Table 3). The tepary accessions and the interspecific lines, increased the value of the leaf stomatal conductance, while the common bean decreased it, under AT (Table 3).

\section{Correlation among shoot and root morpho-physiological variables}

Positive correlations $(\mathrm{P} \leq 0.01)$ were observed between shoot biomass and root biomass of plants under $\mathrm{HT}(r=0.70)$ and AT $(\mathrm{r}=0.68)$. Positive correlations were observed between shoot and pod biomass under both HT $(r=0.77)$ and AT $(r=0.76)$ and also between shoot biomass and LA under HT $(r=0.63)$ and AT $(r=0.55)$. Highly significant positive correlations $(\mathrm{P} \leq 0.01)$ were observed between pod biomass and pod number of plants under HT $(r=0.72)$ and AT $(r=0.85)$. Pod biomass was negatively correlated $(\mathrm{P} \leq 0.01)$ with number of days to flowering under HT $(r=-0.65)$ and AT $(r=-0.49)$. The tepary accessions that bloomed early had higher pod biomass under both conditions (Figures 1a, 1b). At HT, positive correlations were observed between pod biomass and the amount of dead leaves at the mid-pod filling stage ( $\mathrm{g} /$ plant $)(\mathrm{P} \leq 0.01 ; \mathrm{r}=0.72)$ (Figures $2 \mathrm{a}, 2 \mathrm{~b})$, and also with the stem biomass $(\mathrm{P} \leq 0.05 ; \mathrm{r}=$ $0.30)$ and root biomass $(\mathrm{P} \leq 0.05 ; \mathrm{r}=0.342)$. With respect to morpho-physiological variables, positive correlations were observed between pod biomass and SPAD readings ( $\mathrm{P} \leq 0.01 ; \mathrm{r}$ $=0.37$ ) under AT. For the root traits, positive correlations $(\mathrm{P} \leq 0.05)$ were observed between total root length and stem biomass of plants under HT $(r=0.33)$ and AT $(\mathrm{P} \leq 0.01, \mathrm{r}=$ $0.43)$. Total root length was correlated with stem diameter under HT $(\mathrm{P} \leq 0.01 ; \mathrm{r}=0.47)$ and AT $(\mathrm{r}=0.53)$, with leaf biomass under HT $(\mathrm{P} \leq 0.01 ; \mathrm{r}=0.40)$ and AT $(\mathrm{P} \leq 0.01, \mathrm{r}=0.45)$ and also with the amount of dead leaves at mid-pod filling ( $\mathrm{g} / \mathrm{plant})$ under HT $(\mathrm{P} \leq 0.05 ; \mathrm{r}=0.32)$. Total root length was positively correlated with the number of nodules (data not shown) under HT (P $\leq 0.01$; $\mathrm{r}=0.54)$, AT $(\mathrm{P} \leq 0.01, \mathrm{r}=0.61)$, and root biomass $(\mathrm{P} \leq 0.01)$ under HT $(r=0.54)$ and AT $(r=0.61)$. Under HT, highly significant positive correlations $(\mathrm{P} \leq 0.01)$ were observed between root biomass and number of pods and number of nodules. Under AT, the root biomass showed the same correlations, except with number of pods which was not correlated (Figures $2 \mathrm{a}, 2 \mathrm{~b})$. Under HT, the variables 'length' and 'biomass of the roots' were positively correlated with SPAD readings and leaf stomatal conductance. Total root length was positively correlated with leaf area (LA) under HT $(\mathrm{P} \leq 0.01 ; \mathrm{r}=0.42)$ and $\mathrm{AT}(\mathrm{P} \leq$ $0.01, \mathrm{r}=0.46)$, and a correlation between root biomass and LA was observed under HT $(\mathrm{P} \leq 0.01, \mathrm{r}=0.74)$ and AT $(\mathrm{P} \leq 0.01, \mathrm{r}$ $=0.77$.

\section{3 | Page}




\section{Multivariate analysis of shoot and root morpho- physiological variables}

Principal component analysis (PCA) was performed to identify the major components that could explain much of the total variations observed in the data. The PCA showed that under HT and $\mathrm{AT}$ the first four components represented $89 \%$ and the $86 \%$, respectively, of the total variance (Table 4). Under HT, the first component accounted for $44 \%$ of the variance, the second $27 \%$, the third $9 \%$, and the fourth $8 \%$, while under AT, the first component accounted for $40 \%$ of the variance, the second $29 \%$, the third $11 \%$, and the fourth $6.0 \%$. The dominance of these four components in the PCA suggests that they contained the main variables that discriminate the genotypes evaluated under HT and AT (Table 4). The quantitative traits that separate genotypes in the first component included LA and total root biomass under HT and AT. Under HT, two different root traits: length and superficial area, separates genotypes, while the number of nodules separated the genotypes under AT. The traits that contributed most to the discrimination in the second component are shoot biomass, pod number, and specific root length under HT and AT. In the third component, the separation of genotypes was mainly due to: efficiency of photosystem II, days to flowering under HT and dead leaf biomass at mid-pod filling under AT. In the fourth component the main traits were, biomass and number of nodules under HT, and the efficiency of photosystem II and SPAD readings under AT (Table 4)

\section{Discussion}

\section{Heat stress induced changes in shoot attributes}

High temperature stress increased pod biomass of P. acutifolis, $P$. vulgaris and interspecific lines, but most notably for the tepary accessions, especially the heat tolerant line G40001, confirming the heat stress tolerance of this species (Rainey and Griffiths, 2005; Chaves, 2015). This is an unexpected result but this superior performance under heat stress conditions is due to the improved genetic adaptation of both tepary accessions and interspecific lines that were used for evaluation in this study. Regarding the common bean lines, A774 and BAT 477 were reported as elite lines for tolerance to abiotic stress based on having a higher number of seeds per plant (Ojeda, 2015). As far as interspecific lines are concerned, the increase of pod biomass under HT stress may be explained by the genetic contribution of $P$. acutifolius in the pedigree of the lines evaluated. Under HT condition, only tepary bean accessions increased dead leaf biomass (accelerated senescence) at mid-pod filling. Positive correlations were observed between this variable and the pod biomass production (Table 2). This correlation was especially important for G40022, G40001 and G40200 accessions, and it was attributed to a greater plant efficiency and remobilization of photosynthates to seed production (Beebe et al., 2009, Polania et al., 2016; Rao et al., 2016). Dry matter partitioning to pods in snap beans has been observed to be efficient for the heat-tolerant cultivar Haisbushi compared to the heat-sensitive cultivar Kentucky Wonder. The photosynthates from the vegetative parts were mobilized to pods for $\mathrm{cv}$. Haisbushi but not for $\mathrm{cv}$. Kentucky Wonder (Omae et al., 2007). Number of pods/plants decreased under HT condition for tepary bean G40022 and G40277 accessions, which is in agreement with the results of Rainey and Griffiths (2005). However, unlike the results reported by these authors under $35^{\circ} \mathrm{C}$ day $/ 32{ }^{\circ} \mathrm{C}$ night conditions, the G40005 and G40278 accessions studied here showed increased number of pods/plants under stress conditions. This difference is possibly due to the $\mathrm{HT}$ conditions used in our study $\left(29^{\circ} \mathrm{C} \pm\right.$ 5 day $/>23^{\circ} \mathrm{C}$ night (up to $27^{\circ} \mathrm{C}$ ). Several authors suggest that the effect of night HT is more critical than day HT. This was confirmed under controlled conditions with night time temperatures of $27^{\circ} \mathrm{C}$ (Porch and Jahn, 2001; Rainey y Griffiths, 2005a; Omae et al., 2012). Temperatures above $30^{\circ} \mathrm{C}$ during the

Table 1. Description of the germplasm investigated in the study: $P$. acutifolius accessions, $P$. vulgaris genotypes and interspecific lines of $P$. vulgaris with P. acutifolius, $P$. coccineus and P. dumosus. day or above $20{ }^{\circ} \mathrm{C}$ during the night result in yield reduction (Rainey and Griffiths, 2005). In our conditions, the HT treatment was $29 \pm 5{ }^{\circ} \mathrm{C}$ during the day and more than $24^{\circ} \mathrm{C}$ (up to $27^{\circ} \mathrm{C}$ ) during the night. We therefore consider that the bean genotypes evaluated in our study were growing under $\mathrm{HT}$ stress conditions. Since $P$. acutifolius is better adapted to higher night temperatures, it performs better under HT during the night than the lower night temperatures in the ambient temperature conditions.

Leaf area increased considerably in common bean and interspecific lines but not in tepary accessions, under HT condition. One accessions (G40022) had the lowest LA and also the highest pod biomass (Table 3 ). This suggests a greater translocation of photosynthates to the pods to the detriment of leaf growth occurred with HT. A significant negative correlation, between pod biomass and days to flowering indicated that earliness contributed to better performance under HT and AT. The tepary bean accessions that flowered earlier had higher pod biomass under both conditions. The HT decreased the number of days to flowering in tepary, while in common bean HT seemed to increase it.

The period of flowering was extended in the heat-sensitive genotypes, which may be a plant survival mechanism. Also, the early flowering of tepary beans was associated with tolerance to high temperatures.

\section{Heat stress induced changes in root attributes}

Yield differences in beans are partly determined by variability in the root system. Larger and deeper root systems are associated with greater tolerance to drought, due to increased soil water extraction. A greater capacity to develop roots that go deep into the soil can provide a better adaptation to conditions of water stress (White and Castillo, 1992; Polania et al., 2009, 2016). There is a direct correlation between tolerance of drought and heat stresses, since during heat stress water availability can be a limitation caused by high temperature. In the present study, high temperature decreased total root length and specific root length in tepary accessions, common bean and interspecific lines. Although in tepary bean accessions, the total root length decreased considerably, compared to the other genotypes under HT conditions. Tepary beans produced more pod biomass and pods per plant, especially for the G40001 accession, suggesting that their tolerance to heat stress is due to a greater efficiency of their root system to utilize available resources. Chaves (2015) also reported a high yield for G40001 under high temperature stress conditions.

\section{Heat stress induced changes in photosynthetic efficiency}

The SPAD readings and photosynthetic efficiency were affected by the high temperature treatment in all genotypes evaluated. Tepary bean accessions had considerably reduced SPAD readings, while common bean lines and interspecific lines were relatively less affected. $P$. acutifolius also had reduced stomatal conductance under HT, while common bean increased it. These results agree with those of Djanaguiraman et al. (2011) and Chaves (2015) who showed that HT stress decreased chlorophyll content and leaf stomatal conductance in soybean and common bean, respectively. The photosynthetic efficiency increased in tepary with HT, while common beans tended to decrease it. The superior adaptation of tepary can be ascribed in part to its ability to regulate stomatal opening and increase photosynthetic efficiency.

\section{Multivariate analysis under heat stress}

The PCA analysis of all traits evaluated showed that four components represented $88.8 \%$ of the total variance under HT conditions. Different traits that were evaluated here appeared to explain the variance in the PCA under HT, but not under AT. The traits in the first component were related to root traits 


\begin{tabular}{|c|c|c|c|}
\hline Genotypes & Origin & Type of germplasm & $\begin{array}{l}\text { Seed } \\
\text { color }\end{array}$ \\
\hline \multicolumn{4}{|c|}{ P. acutifolius A. Gray germplasm accessions } \\
\hline G40001 & Veracruz (Mexico) & Landrace & White \\
\hline G40005 & La paz (El salvador) & Landrace & White \\
\hline G40022 & Arizona (United States) & Landrace & Yellow \\
\hline G40068 & Arizona (United States) & Landrace & Yellow \\
\hline G40084 & Durango (Mexico) & Landrace & Cream brown \\
\hline G40110 & Campeche (Mexico) & Landrace & Black. cream \\
\hline G40159 & Sonora (Mexico) & Landrace & White \\
\hline G40200 & Guanacaste (Costa Rica) & Landrace & Cream. brown \\
\hline G40277 & Sonora (Mexico) & Landrace & White \\
\hline G40278 & Sonora (Mexico) & Landrace & White \\
\hline \multicolumn{4}{|l|}{ P. vulgaris $\mathrm{L}$. lines } \\
\hline A 774 & Brazil & Inbred line & Cream \\
\hline BAT 477 & Colombia & Inbred line & Cream \\
\hline DAB 295 & Colombia & Inbred line & Red \\
\hline Calima & Colombia & Inbred line & Red \\
\hline \multicolumn{4}{|l|}{ Interspecific lines } \\
\hline INB $827\left(P_{V \times} P_{a}\right)$ & Colombia & Line & Red \\
\hline SEF $60\left(P_{V \times} P a \times P c\right)$ & Colombia & Line & Red \\
\hline ALB $91\left(P_{V} \times\left(P_{V} \times P_{c}\right) F_{1}\right.$ & Colombia & Line & Red \\
\hline SCM $140\left(P_{V \times} P a \times P d\right)$ & Colombia & Line & Purple \\
\hline
\end{tabular}

$P a=$ Phaseolus acutifolius. $P v=P$. vulgaris. $P C=P$. coccineus $L$., $P d=P$. dumosus

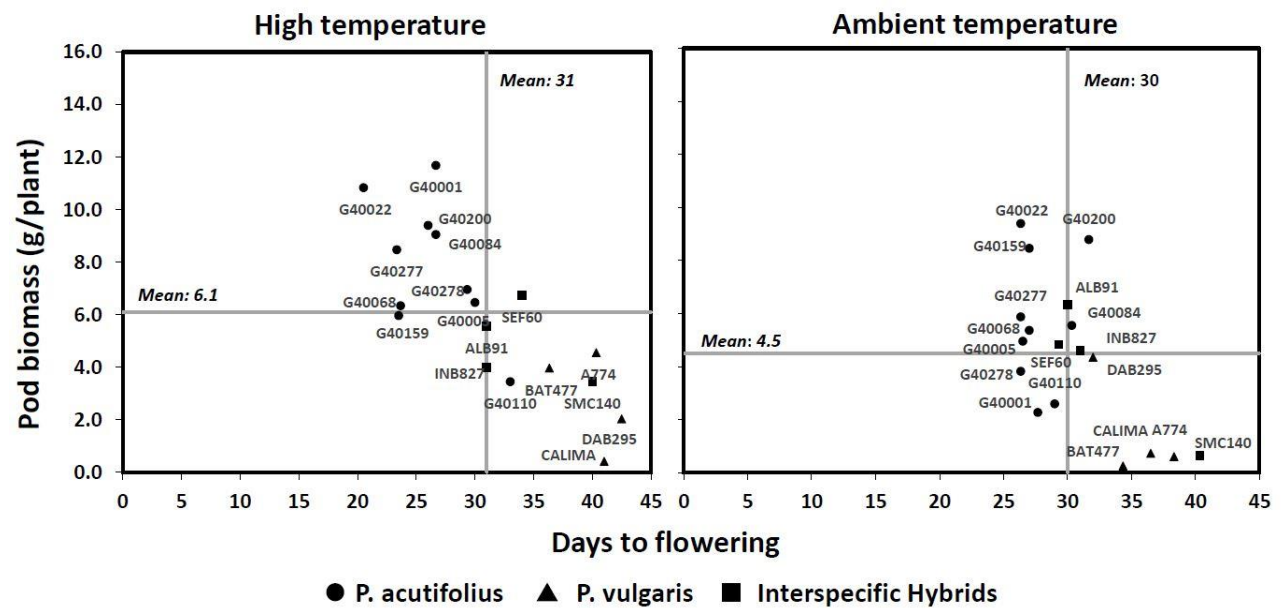

Fig 1. Relationship between pod biomass (g/plant) and days to flowering in P. acutifolius, P. vulgaris. species and the interspecific lines under a) High temperature and b) Ambient temperature conditions. The genotypes that bloomed early and had higher pod biomass were identified in the upper, left hand quadrant for both conditions.

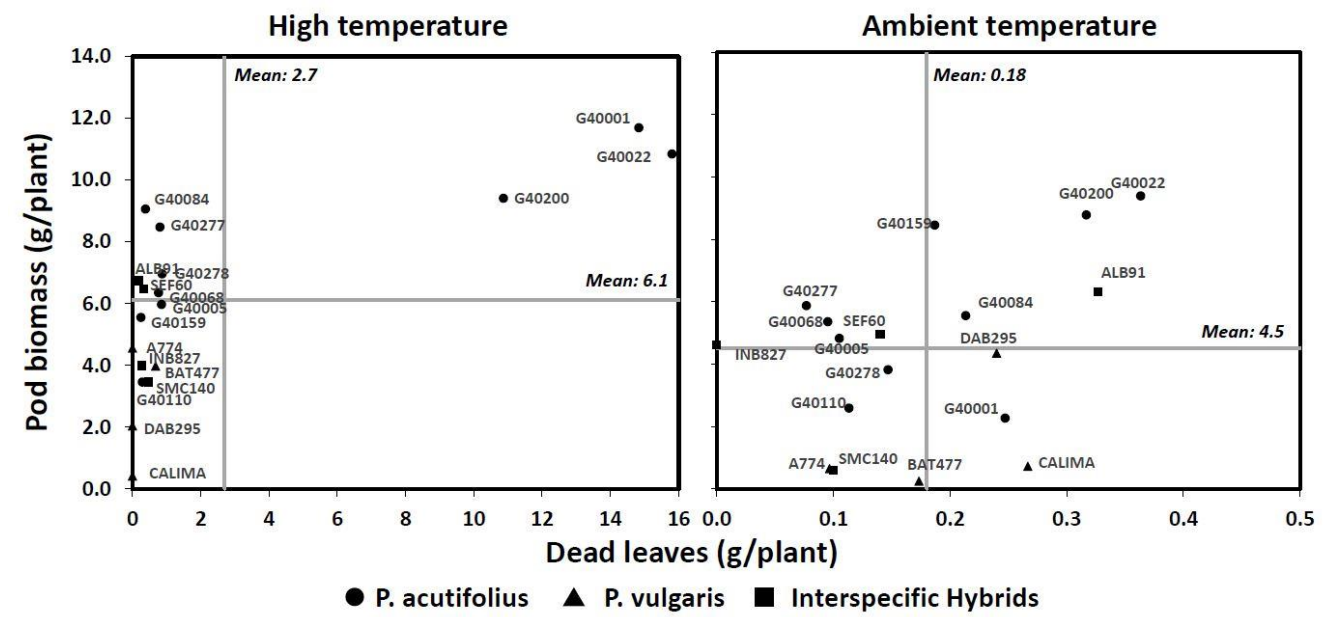

Fig 2. Relationship between pod biomass (g/plant) and dead leaves (g/plant) in P. acutifolius, P. vulgaris species and the interspecific lines under a) High temperature and b) Ambient temperature conditions. The genotypes that had higher pod biomass and show also higher amount of dead leaves were identified in the upper, right hand quadrant for both conditions. 
Table 2. Comparison of the effects of high temperature (HT) with ambient temperature (AT) treatment on mean values of total shoot biomass, dead leaf weight at mid grain filling, pod biomass, pod number and specific root length per plant in lines tested.

\begin{tabular}{|c|c|c|c|c|c|c|c|c|c|c|}
\hline & \multicolumn{2}{|c|}{$\begin{array}{l}\text { Shoot biomass } \\
\text { (g/plant) }\end{array}$} & \multicolumn{2}{|c|}{$\begin{array}{l}\text { Dead leaves } \\
\text { (g/plant) }\end{array}$} & \multicolumn{2}{|c|}{$\begin{array}{l}\text { Pod biomass } \\
\text { (g/plant) }\end{array}$} & \multicolumn{2}{|c|}{$\begin{array}{l}\text { Number of } \\
\text { pods/plants }\end{array}$} & \multicolumn{2}{|c|}{$\begin{array}{c}\text { Specific } \\
\text { root length / } \\
\text { plant (cm/plant)* }\end{array}$} \\
\hline Genotype & HT & AT & HT & AT & HT & AT & HT & AT & HT & AT \\
\hline \multicolumn{11}{|c|}{ Tepary bean } \\
\hline G40001 & 18.1 & $3.5 \mathrm{~d}$ & $14.83 \mathrm{ab}$ & 0.14 & 11.7 & $2.3 \mathrm{def}$ & $17.4 \mathrm{ab}$ & $4.0 \mathrm{def}$ & 697.5 & $5,999.1$ \\
\hline G40005 & 11.1 & $10.3 \mathrm{abc}$ & $0.33 \mathrm{c}$ & 0.09 & 6.5 & $5.0 \mathrm{dc}$ & $10.4 \mathrm{bc}$ & 9.5 bcde & $1,313.8$ & $1,473.7$ \\
\hline G40022 & 14.7 & $12.4 \mathrm{ab}$ & $15.80 \mathrm{a}$ & 0.21 & 10.9 & $9.4 \mathrm{a}$ & $14.5 \mathrm{abc}$ & $17.4 \mathrm{a}$ & $1,486.3$ & $1,762.9$ \\
\hline G40068 & 8.8 & $6.7 \mathrm{bcd}$ & $0.76 \mathrm{abc}$ & 0.15 & 6.4 & $5.4 \mathrm{bcd}$ & $9.0 \mathrm{bc}$ & $9.7 \mathrm{bcd}$ & 625.2 & $3,491.1$ \\
\hline G40084 & 13.1 & $10.7 \mathrm{abc}$ & $0.38 \mathrm{c}$ & 0.36 & 9.1 & $5.6 \mathrm{bcd}$ & $17.0 \mathrm{ab}$ & $10.4 \mathrm{bcd}$ & $1,560.3$ & $1,556.5$ \\
\hline G40110 & 10.4 & $5.9 \mathrm{~cd}$ & $0.29 \mathrm{c}$ & 0.32 & 3.5 & $2.6 \mathrm{def}$ & $9.0 \mathrm{bc}$ & 4.4 cdef & $1,494.3$ & $3,202.4$ \\
\hline G40159 & 8.9 & $12.7 \mathrm{ab}$ & $0.85 \mathrm{abc}$ & 0.25 & 6.0 & $8.5 \mathrm{ab}$ & $10.0 \mathrm{bc}$ & $18.0 \mathrm{a}$ & $2,576.1$ & $1,662.4$ \\
\hline G40200 & 13.8 & $11.0 \mathrm{abc}$ & $10.90 \mathrm{abc}$ & 0.11 & 9.4 & $8.8 \mathrm{ab}$ & $11.7 \mathrm{bc}$ & $10.4 \mathrm{bcd}$ & $1,146.7$ & 167.7 \\
\hline G40277 & 14.4 & $8.2 \mathrm{abcd}$ & $0.80 \mathrm{abc}$ & 0.19 & 8.5 & $5.9 \mathrm{bcd}$ & $12.4 \mathrm{abc}$ & $13.4 \mathrm{ab}$ & $1,042.7$ & $2,440.5$ \\
\hline G40278 & 10.1 & $5.3 \mathrm{~cd}$ & $0.87 \mathrm{abc}$ & 0.08 & 7.0 & $3.8 \mathrm{cde}$ & $13.4 \mathrm{abc}$ & $10.7 \mathrm{bc}$ & $1,674.4$ & $3,398.3$ \\
\hline Mean & 12.4 & 8.3 & 4.58 & 0.19 & 7.9 & 5.7 & 12.4 & 10.7 & $1,479.7$ & $2,666.4$ \\
\hline \multicolumn{11}{|c|}{ Common bean } \\
\hline A774 & 21.7 & $5.7 \mathrm{~cd}$ & $0.0 \mathrm{c}$ & 0.33 & 4.6 & 0.6 ef & $18.0 \mathrm{ab}$ & $5.7 \mathrm{cdef}$ & $1,032.5$ & $2,632.1$ \\
\hline BAT477 & 17.3 & $5.9 \mathrm{~cd}$ & $0.68 \mathrm{abc}$ & 0.09 & 4.0 & $0.2 \mathrm{f}$ & $16.7 \mathrm{ab}$ & $3.4 \mathrm{ef}$ & 905.3 & $2,675.5$ \\
\hline DAB295 & 6.4 & $13.7 \mathrm{a}$ & $0.0 \mathrm{c}$ & 0.10 & 2.0 & $4.4 \mathrm{~cd}$ & $2.0 \mathrm{c}$ & $6.5 \mathrm{cdef}$ & $2,906.8$ & $1,077.9$ \\
\hline Calima & 6.2 & $2.4 \mathrm{~d}$ & $0.0 \mathrm{c}$ & 0.0 & 0.4 & 0.7 ef & $3.0 \mathrm{c}$ & $2.0 \mathrm{f}$ & $2,564.3$ & $4,525.7$ \\
\hline Mean & 12.9 & 6.9 & 0.17 & 0.13 & 2.7 & 1.5 & 9.4 & 4.4 & $1,852.2$ & $2,727.8$ \\
\hline \multicolumn{11}{|c|}{ Interspecific lines } \\
\hline INB827 & 12.8 & $12.5 \mathrm{ab}$ & $0.27 \mathrm{c}$ & 0.17 & 4.00 & $4.6 \mathrm{~cd}$ & $10.0 \mathrm{bc}$ & $10.4 \mathrm{bcd}$ & $1,121.7$ & $1,711.1$ \\
\hline SEF60 & 13.4 & $8.5 \mathrm{abcd}$ & $0.19 \mathrm{c}$ & 0.24 & 6.74 & $4.8 \mathrm{~cd}$ & $9.0 \mathrm{bc}$ & $6.0 \mathrm{cdef}$ & $1,415.1$ & $1,969.8$ \\
\hline SMC140 & 17.9 & $13.3 \mathrm{a}$ & $0.48 \mathrm{c}$ & 0.10 & 3.50 & $0.6 \mathrm{ef}$ & $25.0 \mathrm{a}$ & $2.7 \mathrm{f}$ & 850.7 & $2,239.1$ \\
\hline ALB91 & 16.9 & $6.7 \mathrm{bcd}$ & $0.25 \mathrm{c}$ & 0.27 & 5.60 & $6.3 \mathrm{abc}$ & $13.0 \mathrm{abc}$ & $10.0 \mathrm{bcd}$ & 951.1 & $1,966.4$ \\
\hline Mean & 15.2 & 10.1 & 0.30 & 0.20 & 4.9 & 4.1 & 14.3 & 7.3 & $1,084.6$ & $1,971.6$ \\
\hline
\end{tabular}

* Means between a yield component and treatment not followed by the same letters are significantly different at $\mathrm{P} \leq 0.05$ according to Duncan's multiple rang test. *Specific root length=root length / root biomass.

(length and surface area), the second ones to physiological variables (efficiency of photosystem and days to flowering) and the third ones to biomass and number of nodules. This indicates that these variables and others that were identified from the univariate analysis (pod biomass, dead leaves at mid grain filling and leaf area) could be used in bean breeding programmes as selection criteria to screen bean genotypes for tolerance to heat stress.

The mean agronomic data obtained from interspecific lines is mixed. For shoot biomass, dead leaves and pod biomass they showed a better response than common bean in high temperature conditions, indicating positive inheritance from other species ( $P$. acutifolius, $P$. coccineus and $P$. dumosus). However, for other traits (number of pods, specific root length and root length) the performance was worse than that of common bean. This indicates that more breeding is required to introgress genes into common bean for yield improvement under heat stress conditions.

\section{Material and methods}

\section{Plant materials}

A total of 18 genotypes were tested: ten accessions of tepary bean (Phaseolus acutifolius A. Gray), four genotypes of common bean (Phaseolus vulgaris L.) and four interspecific lines from crosses of $P$. vulgaris with $P$. acutifolius, $P$. coccineus and $P$. domosus (Table 1). The common bean genotypes were developed to improve adaptation to different stresses: The A774 genotype was developed for improved adaptation to low soil fertility, BAT 477 was developed for improved adaptation to low soil phosphorus availability and drought, while DAB 295 was developed to tolerate drought and Calima was included as a commercial check. Four interspecific lines were included. SEF 60 was obtained from the cross (ALB74 x INB 841) F 1 RCB593; ALB74 was obtained from the cross SER $16 \times$ (SER $16 \times$ G35346-3Q) $F_{1}$ with genes from P. coccineus (Butare et al., 2012). INB841 was derived from the cross (INB108 x INB605) (Mejia et al., 1994). INB 827 was obtained from the cross (INB $108 \times$ INB 105) with genes from P. acutifolius (Mejia et al., 1994). SMC140 was obtained from the cross (INB $841 \times$ SMC6) $F_{1} \times\left(\right.$ SXB $405 \times$ MIB 780) $F_{1}$, where the INB 841 and the MIB 780 are interspecific lines of $P$. vulgaris $\mathrm{x} P$. acutifolius and $P$. vulgaris $\mathrm{x} P$. dumosus, respectively. ALB 91, an interspecific line obtained from the cross SER 16 x (SER $16 \mathrm{x}$ G35346B) $F_{1}$ with genes from P. coccineus (Butare et al., 2012) (Table 1). The tepary bean germplasm accessions, and the common bean genotypes and the interspecific lines were obtained from the Genetic resources Unit and the Bean Programme of CIAT, respectively.

\section{Experimental conditions}

The experiments were conducted at the International Center for Tropical Agriculture (CIAT) in Palmira, Colombia, located at latitude $3^{\circ} 29^{\prime} \mathrm{N}$, longitude $76^{\circ} 21^{\prime} \mathrm{W}$ and 965 altitude above sea level. Two experiments were conducted simultaneously to evaluate the tolerance of the various bean genotypes to high temperature. Both experiments were conducted using a split-plot design with three replications. Experiment 1 was carried out with high temperature treatment (HT) in a greenhouse and Experiment 2 was realized at ambient temperature (AT), outdoors in the field under rainout shelter. Seeds were sown in transparent plastic cylinders (120 cm long, $7.5 \mathrm{~cm}$ diameter) with a Mollisol soil from Palmira, Colombia (Polania et al., 2009). Soil cylinders were carefully packed with a 2:1 soil: sand mixture having a final bulk density of $1.4 \mathrm{~g} / \mathrm{cm}^{3}$. The seeds were germinated in paper towels and uniform seedlings were selected for transplanting to transparent plastic cylinders, each of which was inserted into PVC sleeve tubes. The plants of both experiments were inoculated at 10 days after sowing with Rhizobium tropici (strain CIAT 899). To induce high temperature 
Table 3. Effect of high temperature (HT) compared to ambient temperature (AT) treatment on SPAD chlorophyll meter reading, photosynthetic efficiency, stomatal conductance, leaf area and days to flowering of 18 Phaseolus genotypes.

\begin{tabular}{|c|c|c|c|c|c|c|c|c|c|c|}
\hline \multirow[t]{2}{*}{ Genotype } & \multicolumn{2}{|c|}{$\begin{array}{l}\text { SPAD chlorophyll } \\
\text { meter reading }\end{array}$} & \multicolumn{2}{|c|}{$\begin{array}{l}\text { Photosynthetic } \\
\text { efficiency (QY } \\
\text { (Fv/FM)) }\end{array}$} & \multicolumn{2}{|c|}{$\begin{array}{l}\text { Stomatal conductance } \\
\left(\mathrm{mmol} \cdot \mathrm{m}^{-2} \cdot \mathrm{s}^{-1}\right)\end{array}$} & \multicolumn{2}{|c|}{ Leaf area $\left(\mathrm{cm}^{2}\right)$} & \multicolumn{2}{|c|}{ Days to flowering } \\
\hline & HT & AT & HT & AT & HT & AT & HT & AT & HT & AT \\
\hline \multicolumn{11}{|c|}{ Tepary bean } \\
\hline G40001 & 30.5 abc* & $45.0 \mathrm{ab}$ & $0.66 \mathrm{ab}$ & 0.57 & 176.2 & 248.0 bcde & $451.7 \mathrm{de}$ & $108.3 \mathrm{ef}$ & $27 \mathrm{efgh}$ & $28 \mathrm{~d}$ \\
\hline G40005 & $31.7 \mathrm{abc}$ & $39.5 \mathrm{abcd}$ & $0.70 \mathrm{a}$ & 0.56 & 239.2 & $443.4 \mathrm{abc}$ & $467.7 \mathrm{de}$ & 539.0 bcde & 30defg & $27 \mathrm{~d}$ \\
\hline G40022 & $27.4 \mathrm{abcd}$ & $40.1 \mathrm{abcd}$ & $0.72 \mathrm{a}$ & 0.60 & 170.1 & 324.3 abcde & $108.0 \mathrm{e}$ & 208.7 def & $21 \mathrm{~h}$ & $26 \mathrm{~d}$ \\
\hline G40068 & $16.4 \mathrm{dc}$ & $28.3 \mathrm{e}$ & $0.58 \mathrm{ab}$ & 0.60 & 276.8 & 263.8 bcde & $104.3 \mathrm{e}$ & $84.3 \mathrm{f}$ & $24 \mathrm{gh}$ & $27 d$ \\
\hline G40084 & $32.7 \mathrm{abc}$ & $41.4 \mathrm{abcd}$ & $0.70 \mathrm{a}$ & 0.58 & 329.0 & 397.7 abcd & $367.3 \mathrm{de}$ & $401.7 \mathrm{cdef}$ & $27 \mathrm{efgh}$ & $30 \mathrm{bcd}$ \\
\hline G40110 & $31.5 a b c$ & $41.7 \mathrm{abcd}$ & $0.71 \mathrm{a}$ & 0.50 & 300.8 & $83.3 \mathrm{ed}$ & 760.7 cde & $294.0 \mathrm{def}$ & $33 \mathrm{cdef}$ & $29 \mathrm{~cd}$ \\
\hline G40159 & $13.4 \mathrm{~d}$ & $47.3 \mathrm{ab}$ & $0.68 \mathrm{ab}$ & 0.58 & 191.6 & $272.5 \mathrm{bcde}$ & $96.5 \mathrm{e}$ & $332.3 \mathrm{cdef}$ & $24 \mathrm{gh}$ & $27 \mathrm{~d}$ \\
\hline G40200 & $18.4 \mathrm{bcd}$ & $48.2 \mathrm{a}$ & $0.70 \mathrm{a}$ & 0.59 & 192.8 & $224.9 \mathrm{cde}$ & $384.0 \mathrm{de}$ & $156.3 \mathrm{def}$ & $26 \mathrm{fgh}$ & $32 \mathrm{bcd}$ \\
\hline G40277 & $24.4 \mathrm{abcd}$ & $43.1 \mathrm{abc}$ & $0.68 \mathrm{ab}$ & 0.61 & 184.4 & $163.7 \mathrm{e}$ & $369.7 \mathrm{de}$ & $140.0 \mathrm{ef}$ & $23 \mathrm{gh}$ & $26 \mathrm{~d}$ \\
\hline G40278 & $37.1 \mathrm{a}$ & $48.2 \mathrm{a}$ & $0.70 \mathrm{a}$ & 0.49 & 205.6 & $320.7 \mathrm{abcd}$ & $164.3 \mathrm{e}$ & $140.3 \mathrm{ef}$ & 29 defg & $26 \mathrm{~d}$ \\
\hline Mean & 26.3 & 42.3 & 0.68 & 0.57 & 226.6 & 284.2 & 327.4 & 240.5 & 26 & 28 \\
\hline \multicolumn{11}{|c|}{ Common bean } \\
\hline A774 & $35.7 \mathrm{ab}$ & 33.4 cde & $0.51 \mathrm{bc}$ & 0.57 & 409.3 & $147.4 \mathrm{e}$ & $1,876.0 \mathrm{a}$ & 521.7 bcdef & $36 \mathrm{abcd}$ & $34 \mathrm{abcd}$ \\
\hline BAT477 & $37.6 \mathrm{a}$ & $31.8 \mathrm{cde}$ & $0.69 \mathrm{a}$ & 0.59 & 316.7 & $197.4 \mathrm{de}$ & $1,483.0 \mathrm{ab}$ & $596.3 \mathrm{bcd}$ & $40 \mathrm{abc}$ & $38 \mathrm{ab}$ \\
\hline CALIMA & $36.2 \mathrm{a}$ & $31.2 \mathrm{de}$ & $0.71 \mathrm{a}$ & 0.61 & 342.5 & $119.2 \mathrm{e}$ & $775.0 \mathrm{cde}$ & $200.5 \mathrm{def}$ & $41 \mathrm{ab}$ & $37 \mathrm{abc}$ \\
\hline DAB295 & $27.0 \mathrm{abcd}$ & 36.6 bcde & $0.36 \mathrm{c}$ & 0.64 & 225.5 & $449.0 \mathrm{ab}$ & $660.0 \mathrm{de}$ & $1354.5 \mathrm{a}$ & $42.5 \mathrm{a}$ & $32 \mathrm{bcd}$ \\
\hline Mean & 34.1 & 33.2 & 0.57 & 0.60 & 323.5 & 228.3 & 1198.5 & 668.3 & 40 & 35 \\
\hline \multicolumn{11}{|c|}{$\begin{array}{l}\text { Interspecific } \\
\text { lines }\end{array}$} \\
\hline INB827 & $33.7 \mathrm{abc}$ & $43.0 \mathrm{abc}$ & $0.66 \mathrm{ab}$ & 0.61 & 362.5 & 243.9 bcde & $905.3 \mathrm{~b}$ & $996.5 \mathrm{bcd}$ & 31 defg & $31 \mathrm{bcd}$ \\
\hline SEF60 & $38.8 \mathrm{a}$ & $41.0 \mathrm{abcd}$ & $0.68 \mathrm{ab}$ & 0.6 & 294.8 & 253.8 bcde & $996.0 \mathrm{bcd}$ & $413.0 \mathrm{cdef}$ & 34 bcde & $29 \mathrm{~cd}$ \\
\hline SMC140 & $36.8 \mathrm{a}$ & 32.4 cde & $0.71 \mathrm{a}$ & 0.58 & 325.5 & 342.4 abcde & $1,535.7 \mathrm{ab}$ & $586.3 \mathrm{bcd}$ & $40 \mathrm{abc}$ & $40 \mathrm{a}$ \\
\hline ALB91 & $39.7 \mathrm{a}$ & $39.8 \mathrm{abcd}$ & $0.65 \mathrm{ab}$ & 0.61 & 265.9 & $491.5 \mathrm{a}$ & $1,416.0 \mathrm{abc}$ & $742.0 \mathrm{bc}$ & 31 defg & $30 \mathrm{bcd}$ \\
\hline Mean & 37.2 & 39.1 & 0.68 & 0.60 & 312.1 & 332.9 & 1213.25 & 684.5 & 34 & 33 \\
\hline
\end{tabular}

* Means between a yield component and treatment not followed by the same letters are significantly different at $\mathrm{P} \leq 0.05$ according to Duncan's multiple

conditions and simulate the changes in temperature between day and night, conditions in the greenhouse were modified using heaters, the ventilation system and thermostats. The HT treatment was set at $29^{\circ} \mathrm{C} \pm 5$ during the day and $>24^{\circ} \mathrm{C}$ (up to $27^{\circ} \mathrm{C}$ ) during the night, with an average relative humidity of 65 $\%$. In the field, average temperature was $25^{\circ} \mathrm{C} \pm 5$ during the day and $\pm 19{ }^{\circ} \mathrm{C}$ at night, with an average relative humidity of $81 \%$, in both treatments. The soil was maintained at $80 \%$ of field capacity and water was supplied to avoid drought stress. The data on relative humidity and temperature were monitored with thermo-hygrometers that registered the parameters every $15 \mathrm{~min}$. The average, minimal and maximal temperatures were calculated per day.

\section{Measurement of shoot and root morpho-physiological characteristics}

Plants were harvested at 60 days of growth for Experiment 1 and at 70 days of growth for Experiment 2. Days to flowering (DF) were determined for each genotype in each experiment. Days to flowering was defined as the number of days after planting until $50 \%$ of the plants had at least one open flower. At mid-pod filling growth stage, the following non-destructive measurements were made. Leaf area was measured using a leaf area meter (model LI3000, LI-COR, NE, USA). The leaf chlorophyll content of fully expanded leaves was measured using a non-destructive, handheld chlorophyll meter (SPAD-502 chlorophyll meter Minolta camera Co., Ltd., Japan). The principle is based on the difference in light attenuation at wavelengths 430 and $750 \mathrm{~mm}$. From the difference in light attenuation, a numerical SPAD (Soil Plant Analysis Development) unit, ranging from 0 to 80 , is calculated by the microprocessor in the SPAD-502 chlorophyll meter. The efficiency of photosystem II (QY) in leaves adapted to light $\left(\mathrm{Fv}^{\prime} / \mathrm{Fm}^{\prime}\right)$ was also determined. The stomatal conductance $\left.(\mathrm{mmol} \mathrm{m})^{-2} \mathrm{~s}^{-1}\right)$ was measured with a portable leaf porometer
(Deacagon SC-1) on a fully expanded young leaf of one plant within each replication. Measurements were made late in the morning (10:00-12:00 am) on clear and sunny days. The biomass of dead leaves (i.e. fallen, dry leaves) per plant at the mid-pod filling stage was measured. At the time of harvest, plants were cut and dry weights of: shoot biomass, stem, leaves, and pod biomass and pod number per plant were recorded. The roots of each soil cylinder were carefully washed free of soil. The washed roots were scanned as images using a desk scanner. From the scanned images, total root length $\left(\mathrm{cm}\right.$ plant $\left.{ }^{-1}\right)$ and proportion of fine roots or the proportion of roots $(\%)$ with a diameter less than $0.5 \mathrm{~mm}$, were measured through image analysis using Win RHIZO (Reagent Instruments Inc.,

Quebec Canada). Root weight per plant was determined after the roots were dried in an oven at $60^{\circ} \mathrm{C}$ for $48 \mathrm{~h}$.

\section{Statistical analysis}

A separate analysis was conducted for each experiment. The sources of variation within each experiment were replications and genotypes. All data were analyzed using the SAS (v. 9.2). Correlation coefficients were calculated by the PROC CORR. Values marked with $*$ or $* *$ are statistically significant at probability levels of $5 \%$ and $1 \%$, respectively. The mean values were compared using the Duncan test. A complementary analysis of variance was performed to compare genotypes and/or groups of genotypes for the most important variables: the number of days to flowering, the SPAD chlorophyll meter

readings, pod biomass, dead leaves at mid-grain filling, root biomass and root length. The tepary bean accession G40001was used as a heat tolerant check (Rao et al., 2013) to compare with: a) the other tepary accessions, b) the common bean genotypes and c) the interspecific lines. 
Table 4. Eigen values and per cent of total variation and component matrix for the principal component axes - High temperature (HT) and ambient temperature (AT) conditions. Values in bold indicate the traits that were informative in genotype differentiation.

\begin{tabular}{|c|c|c|c|c|}
\hline Principal components & CP1 & CP2 & CP3 & CP4 \\
\hline $\begin{array}{l}\text { High temperature }(\mathrm{HT}) \\
\text { Eigen value }\end{array}$ & 7.09 & 4.29 & 1.49 & 1.33 \\
\hline Variance proportion & 0.44 & 0.27 & 0.09 & 0.08 \\
\hline Cumulative proportion variance & 0.44 & 0.71 & 0.80 & 0.89 \\
\hline Shoot biomass & 0.075 & 0.442 & 0.177 & -0.056 \\
\hline Pod biomass & -0.268 & 0.256 & 0.219 & -0.039 \\
\hline Dead leaf at mid-grain filling & -0.291 & 0.172 & 0.204 & 0.144 \\
\hline Leaf area & 0.318 & 0.179 & 0.253 & -0.022 \\
\hline Pods number & |- 0.006 & 0.403 & 0.182 & 0.261 \\
\hline Days to flowering & 0.285 & -0.118 & 0.369 & 0.081 \\
\hline Roots length & 0.325 & -0.133 & 0.301 & 0.101 \\
\hline Roots volume & 0.297 & -0.202 & 0.243 & 0.189 \\
\hline Roots biomass & 0.303 & 0.250 & 0.121 & 0.018 \\
\hline Supeficiel area of root & 0.314 & -0.172 & 0.274 & 0.149 \\
\hline Specific root length & -0.028 & 0.449 & 0.046 & 0.133 \\
\hline Nodules biomass & 0.223 & 0.237 & 0.267 & -0.458 \\
\hline Nodules number & 0.242 & 0.204 & 0.310 & -0.421 \\
\hline SPAD chlorophyll content & 0.270 & 0.154 & 0.036 & -0.190 \\
\hline Leaf stomatal conductance & 0.292 & -0.002 & 0.255 & 0.216 \\
\hline Efficiency of photosystem II & -0.059 & 0.165 & 0.414 & 0.586 \\
\hline \multicolumn{5}{|l|}{ Ambient temperature (AT) } \\
\hline Eigen value & 6.35 & 4.59 & 1.73 & 1.02 \\
\hline Variance proportion & 0.40 & 0.29 & 0.11 & 0.06 \\
\hline Cumulative proportion of variance & 0.40 & 0.69 & 0.80 & 0.86 \\
\hline Shoot biomass & 0.119 & 0.402 & 0.267 & -0.053 \\
\hline Pod biomass & -0.102 & 0.423 & 0.094 & -0.233 \\
\hline Dead leaf at mid-grain filling & -0.044 & 0.046 & 0.625 & 0.201 \\
\hline Leaf area & 0.345 & 0.092 & -0.179 & 0.210 \\
\hline Pod number & -0.111 & 0.390 & 0.197 & -0.189 \\
\hline Days to flowering & 0.229 & -0.281 & -0.035 & -0.108 \\
\hline Root length & 0.333 & -0.118 & 0.287 & 0.047 \\
\hline Root volume & 0.331 & -0.180 & 0.263 & -0.007 \\
\hline Root biomass & 0.359 & 0.156 & 0.077 & 0.073 \\
\hline Superficial area roots & 0.337 & -0.152 & 0.279 & 0.020 \\
\hline Specific root length & -0.170 & -0.326 & -0.044 & 0.019 \\
\hline Nodules biomass & 0.269 & 0.218 & -0.307 & -0.039 \\
\hline Nodules number & 0.349 & 0.110 & -0.173 & 0.173 \\
\hline Spad chlorophyll content & -0.177 & 0.259 & 0.094 & 0.349 \\
\hline Leaf stomatal conductance & 0.132 & 0.279 & -0.280 & 0.387 \\
\hline Efficiency of photosystem II & 0.227 & 0.104 & -0.075 & -0.705 \\
\hline
\end{tabular}

The tepary group of accessions were also compared with the common bean and the interspecific lines. Finally, the common bean genotypes were compared with the interspecific lines under HT (greenhouse) and AT (rainout shelter) conditions. A combined

analysis of two experiments was also conducted. The sources of variation were: temperature treatments, replication, genotype and genotype $\mathrm{x}$ temperature condition treatment interaction. Principal Component Analysis (PCA) was performed on the measured variables and was based on Pearson correlation matrix and Euclidean distances. Eigenvalues for all principal components (PCs) are shown. Eigenvectors generated by the PCA were used to identify parameters that best differentiated the genotypes in each experiment.

\section{Conclusion}

Tepary bean exhibits traits related to adaptation to high temperature. Beneficial morpho-physiological traits include a greater capacity to allocate dry matter to pods, fine roots and smaller leaves (for efficient water use and reduced stomatal conductance). Three tepary bean accessions that produced good pod biomass under heat stress were identified: G40001 (Veracruz, Mexico), G40022 (Arizona, United States) and G40200 (Guanacaste, Costa Rica). These accessions could serve as potential donors of genes to improve common bean through interspecific hybridizations and backcrossing. Alternatively, breeding of tepary beans for preferred consumer traits may be considered to safe guard food security in arid zones of the world.

\section{Acknowledgments}

We acknowledge partial support from the International Atomic Energy Agency (IAEA), Vienna, Austria for the project on "Heat effects in tepary beans and its relatives". We are grateful to the Bill and Melinda Gates Foundation (BMGF), and the CGIAR Research Program on Grain Legumes for financial support of research on improving drought resistance in common bean. We would also like to thank all donors who supported this work through their contributions to the CGIAR Fund and the National University of Colombia-Palmira.

\section{References}

Beebe S, Rao I, Blair M, Butare L (2009) Breeding for abiotic stress tolerance in common bean: present and future challenges. S J Breed Genet. 41:1-11.

Bielenberg D, Miller J, Berg V (2003) Paraheliotropism in two Phaseolus species: combined effects of photon flux density and pulvinus temperature, and consequences for leaf gas exchange. Environ Exp Botany. 49:95-105.

Blair M, Pantoja W, Muñoz L (2012) First use of microsatellite markers in a large collection of cultivated and wild accessions 
of tepary bean (Phaseolus acutifolius A. Gray). Theor Appl Genet. 125:1137-1147.

Butare L, Rao I, Lepoivre P, Polania J, Cajiao, Cuasquer C, Beebe S (2012) Phenotypic evaluation of interspecific recombinant inbred lines (RILs) of Phaseolus species for aluminium resistance and shoot and root growth response to aluminiumtoxic acid soil. Euphytica 186 (3):715-730.

Chaves N-F (2015) Uso de recombinantes de Phaseolus. vulgaris L., P. coccineus L. y $P$. acutifolius A. Gray, para mejorar la tolerancia del frijol común a diferentes tipos de estrés abiótico. Tesis de Doctorado, Universidad Nacional de Colombia, Palmira, Colombia, Junio 2015.

Djanaguiraman M, Prasad P, Boyle V, Schapaugh D (2011) High temperature stress and soybean leaves: Leaf anatomy and photosynthesis. Crop Sci. 51:2125-2131.

Freeman G (1912) Southwestern beans and teparies. Bull Univ Ariz Agric Exp. Stn. 68:1-55.

Gepts P, Debouck D (1991) Origin, domestication, and evolution of common bean (P. vulgaris L.). In: Schoonhoven AV (ed) Common bean: Research for crop improvement, CAB Intern., Wallingford, UK, 7-53.

IPCC 2007: Climate change 2007: The physical science basis contribution of working group to the fourth assessment report of the IPCC. In Solomon, S, Qin D, Manning M, Chen Z, Marquis M, Averyt KB, Tignor M, Miller HL (eds) Cambridge University Press, Cambridge, United King dom, New York, N.Y, USA.1-18.

Lin T, Markhart A (1990) Temperature effects on mitochondrial respiration in Phaseolus acutifolius a. Gray and P. vulgaris L. Plant Physiol. 94:54-58.

Lin T, Markhart A (1996) Phaseolus acutifolius A. Gray is more heat tolerant than P. vulgaris in the absence of water stress. Crop Sci. 36:110-114.

Markhart A (1985) Comparative water relations of Phaseolus vulgaris L. and Phaseolus acutifolius A. Gray. Plant Physiol. 77:113-117.

Mejía J, Muñoz C, Jacobsen H, Roca W, Singh S (1994) Interspecific hybridization between common and tepary beans: Increased embryo growth, and efficiency of hybridization through recurrent and congruity backcrossing. Theor Appl Genet. 88:324-331.

Muñoz L, Blair M, Duque M, Thome J, Roca W (2004) Introgression in common bean $\mathrm{x}$ tepary bean interspecific congruity-backcross lines as measured by AFLP markers. Crop Sci. 44:637-645.
Muñoz L, Duque M, Debouck D, Blair M (2006) Taxonomy of tepary bean and wild relatives as determined by amplified fragment length polymorphism (AFLP) markers. Crop Sci. 46:1744-1754.

Nabhan G, Felger R (1978) Teparies in southwestern North America: a biogeographical and etnohistorial study of Phaseolus acutifolius. Econ Bot. 32:2-19.

Ojeda, L (2015) Reaccion de Phaseolus acutifolius A. Gray y relacionados a dos patogenos del suelo y a estrés abiotico. Tesis de maestria. Universidad Nacional de Colombia, Palmira, Colombia. P 48.

Omae H, Kumar A, Kashiwaba K, Shono M (2007) Influence of temperature shift after flowering on dry matter partitioning in two cultivars of snap bean (Phaseolus vulgaris) that differ in heat tolerance. Plant Prod Sci. 10:14-19.

Polanía J, Rao I, Beebe S, García R (2009) Desarrollo y distribución de raíces bajo estrés por sequía en frijol común (Phaseolus vulgaris L.) en un sistema de tubos con suelo. Agron Colomb. 27:25-32.

Polania J, Poschenrieder C, Beebe S, Rao I (2016) Effective use of water and increased dry matter partitioned to grain contribute to yield of common bean improved for drought resistance. Front Plant Sci. 7:660.doi:10.3389/fpls.2016.00660.

Porch T, Beaver J, Debouck D, Jackson S, Kelly J, Dempewolf H (2013) Use of wild relatives and closely related species to adapt common bean to climate change. Agronomy. 3: 433-461. Rainey K, Griffiths P (2005a) Evaluation of Phaseolus acutifolius A. Gray plant introductions under high temperatures in a controlled environment. Genet Resour Crop Evol. 52: 117-120.

Rainey K, Griffiths P (2005b) Differential response of common bean genotypes to high temperature. J Am Soc Hort Sci. 130 (1):18-23.

Rao I, Beebe S, Polania J, Ricaute J, Cajiao C, Garcia R, Rivera M (2013) Can tepary bean be a model for improvement of drought resistance in common bean? Afr J Crop Sci. 21:265281.

Rao I, Beebe S, Polania J, Grajales M, Cajiao C, Ricaurte J, Garcia R, Rivera M (2016) Evidence for genotypic differences among elite lines of common bean in their ability to remobilize photosynthate to increase yield under drought. J Agric Sci. 155:857-875.

White J, Castillo J (1992) Evaluation of diverse shoot genotypes on selected root genotypes of common bean under soil water deficits. Crop Sci. 32:762-765. 